\title{
The imitation game
}

\author{
Being human.
}

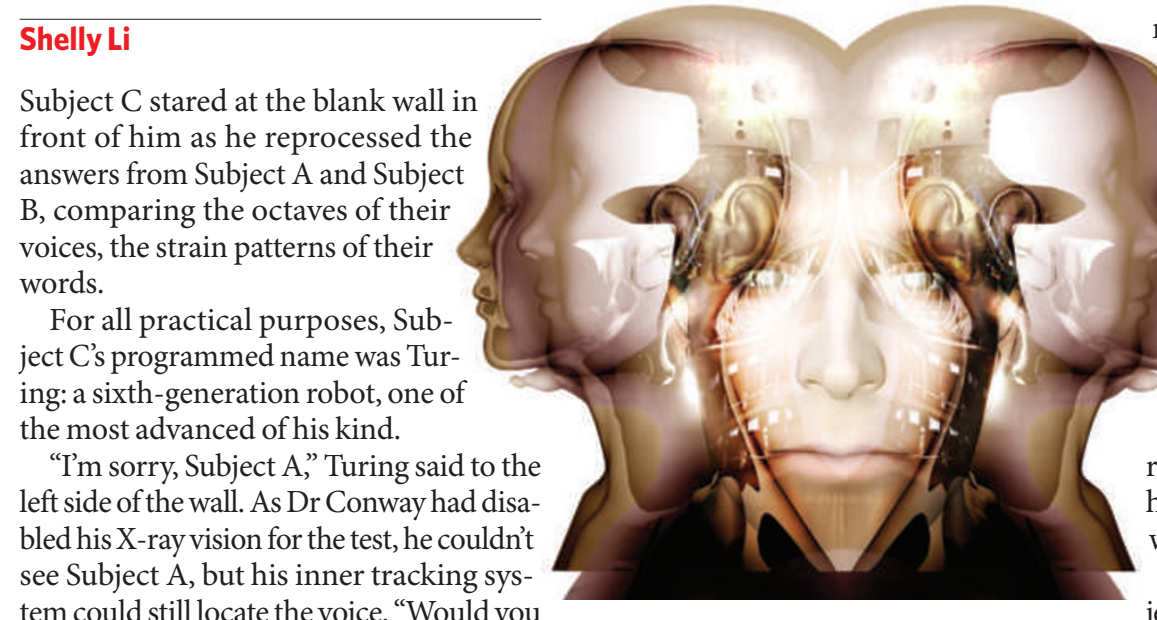
tem could still locate the voice. "Would you repeat the answer to my last question. How is your relationship with your wife?"

Turing increased the power of his inner sound reception just in time to hear the soft scoff that he wouldn't have caught otherwise.

In a woman's voice, Subject A repeated: "I don't have a wife. I'm a woman. Not that I don't approve of gay people, mind you. I'm a Democrat, and it's 2065, for Christ's sake - half my graduating class swung both ways."

Turing frowned. Swung both ways. He had been confused about the phrase the first time it was said. "What does the phrase 'swing both ways' mean?"

"Oh." There was a light chuckle. "It means that a person is, uh, attracted to members of both sexes."

"I see." Turing recorded the definition and filed it away.

He then sat back in his chair and evaluated. Subject A had to be the woman, and Subject B had to be the man.

But Subject B is a convincing woman too, Turing thought.

He had to be careful of which gender to place on which subject. Dr Conway had warned him to weigh the answers he received from the two subjects. One person was lying on every question, whereas the other always told the truth.

Inside the viewing area above the testing room, Dr Conway watched from behind a one-way mirror as Turing struggled to choose. The programmer on Conway's right monitored Turing's processing system, as well as the robot's emitted levels of artificial intelligence.

As Conway stood there, seeing Turing on one side of the wall and the two subjects on the other, he couldn't help feeling a twinge of pity for the unknowing robot.
Before starting the test, dubbed 20 years ago by Conway's mentor as 'the imitation game, Turing had given Conway a promise to pass the test, and had said it with such determination in his human-looking eyes. Conway had to admit: he had never seen so much emotion behind a robot, so much fire and passion.

Conway's mentor, Dr Maigney, had always had to remind him that the robots would never have a 'mind'. Sure, by the sixth generation, robots looked so real that you couldn't distinguish them from human beings. Robots could talk slang they could even tell jokes. But that didn't mean they had thoughts of their own. All they had was artificial intelligence, words and actions that they had learned by mimicking humans.

As a scientist, Conway still had trouble with these facts.

The imitation game continued.

"Subject B," Turing said, his eyes flickering to the right of the wall. "Do you hold a job?"

"I work part-time as a dental assistant." The womanly voice was steady, even.

"And what do you do with the rest of your time?"

"I clean the house, cook, take care of my kids ... you know."

Being a robot that had never left the factory, Turing didn't, but that was a trivial matter. He asked Subject B: "Do you have a husband? Or a wife? Perhaps you swing both ways?"

Subject B giggled. "My kids have a father who sends us plenty of money every month." Then the frequencies in the voice faltered. "But no, I don't have a husband."

"Hmm." Slowly, a smile spread across Turing's face. He had the answer now.

"Dr Conway," said the programmer who

monitored Turing's artificial intelligence.

"His AI level just peaked. He's got the answer."

Conway said: “Then let's hear it.”

Turing's chair scraped softly across the concrete floor as he turned towards the one-way mirror. "I know who is the man and who is the woman."

“Tell us, Turing," Conway's voice echoed through the room.

Turing's conviction made his heart race with an unsteady beat. Nevertheless, he stood up and said: "Subject B is the woman. Subject A is the man."

Turing hadn't looked to see which subject displayed womanly qualities, and which subject resembled a man - honestly, he didn't know many differences in the characteristics of the two genders. But to Turing's ears, there was a pure tone of vulnerability in Subject B's voice, something that had moved the robot. There was no doubt that Subject B had been telling the truth.

But whether or not Turing's instincts were right would depend on Dr Conway's next words.

After a few moments, Conway said: "Congratulations, Turing. You have passed the test and will be granted human status."

Focusing on the triumphant smile lighting up the robot's face, Dr Conway tuned out the murmuring of programmers throughout the viewing area.

But there was one programmer whose words wormed into Conway's head. He was only a kid, maybe two or three years out of college, and no doubt he was new to the programme.

"Sir," the young man said. "Subject A and Subject B are both computers that we programmed with personalities, nothing more. The imitation game is unwinnable."

"That's correct."

"Then Turing is nothing more than a robot, albeit a very advanced one." The young man peered up at Conway with confusion. "How can you lie to him?"

Conway tore his eyes off Turing and turned to the programmer. With a smile on his face and a churning in his stomach, Conway answered with the same advice that Dr Maigney had given him three years ago. "Because in this world, belief is the only thing that matters."

Shelly Li lives in Omaha, Nebraska, and writes science fiction and fantasy. Visit her website at www.shelly-li.com Join the discussion of Futures in Nature at go.nature.com/QMAm2a 